\title{
OFFICIAL GOMMUNIGATIONS
}

Meetings of the Society have been fixed at the following times and places:

The Summer Meeting of the Society, at Vassar College,

September 6-8, 1923.

Abstracts must be in the hands of the Secretary of the Society not later than August 8.

The San Francisco Section, at Los Angeles, September I7-20, 1923.

Abstracts must be in the hands of the Secretary of the Section, B. A. Bernstein, not later than July 26.

New York City, October 27, 1923.

Abstracts must be in the hands of the Secretary of the Society not later than October 13.

R. G. D. RichardSON, Secretary of the Society.

\section{COLLECTED WORKS OF LEONARD EULER}

On the two-hundredth anniversary of the birth of Euler, a committee of the Society of Swiss Naturalists launched the project of international cooperation for the publication of his collected works. Academies and individuals subscribed for about 300 sets, and about one hundred thousand (100,000) Swiss francs were collected, for the most part in Switzerland; the American Mathematical Society subscribed five thousand $(5,000)$ francs. Eighteen ( 18 ) of the estimated seventy (70) volumes have been published.

By reason of the European War nearly one-half of the subscribers have been unable to meet their obligations in full. Under these circumstances, a considerable number of new subscribers must be secured if the completion of the undertaking is to be possible in the near future. There are three plans for subscribing. Those libraries or individuals wishing for information with a view to joining in promoting this great international undertaking, should communicate with the Official Representative of the Euler Committee for the United States and Canada,

R. C. Archibald, Brown University, Providence, R. I. 


\section{Whole Number 314}

\section{CONTENTS}

PAGE

The April Meeting of the San Francisco Section. By B. A. Bernstein

The April Meeting of the Society in Chicago. By Arnold Dresden.

The April Meeting of the Society in New York. By R.

G. D. Richardson

An Elementary Proof of a Fundamental Lemma concerning the Limit of a Sum. By H. J. EtTuinger

Klein's Collected Papers, Vol. II. By Virgil SNyder

Lévy on Functionals. By C. A. Fischer.

Shorter Notices 232

Notes. 235

New Publications. 238

Any communication intended for this Bulletin may be addressed to the American Mathematical Society, Prince and Lemon Streets, Lancaster, Pa., or may be sent to separate officials of the Society as follows:

Articles for insertion in the Bulletin should be addressed to E. R. Hedrick, Editor of the Bulletin, 304 Hicks Ave., Columbia, Mo. Reviews should be sent to J. W. YounG, Dartmouth College, Hanover, N. H. Notes should be sent to R. W. Burgess, Brown University, Providence, R. I.

Subscriptions to the BuLLETIN, orders for back numbers, and inquiries in regard to non-delivery of current numbers should be addressed to The American Mathematical Society, 50I West I I6th Street, New York.

Advertising space is available in the Bulletin at $\$ 16$ per page, $\$ 9$ per half-page, $\$ 5$ per quarter page, per issue. Address correspondence regarding advertising to H. L. RIETz, University of Iowa, Iowa City, Iowa.

Changes of address of members, exchanges, and subscribers should be communicated at once to the Secretary of the Society, R. G. D. RICHARDson, 50I West I I6th Street, New York.

The initiation fees $(\$ 5.00)$ and annual dues $(\$ 6.00)$ of members of the Society are payable to the Treasurer of the Society, W. B. Fite, 50I West I I6th Street, New York. 